\title{
Dampak Proses Sintering Material Keramik pada Sifat Mekanik dan Dimensi Suatu Produk
}

\author{
Sulistyo \\ Departemen Teknik Mesin, Fakultas Teknik, Universitas Diponegoro \\ Jl. Prof. Sudharto, SH., Tembalang-Semarang 50275, Telp. +62247460059 \\ E-mail: listyotm@ft.undip.ac.id
}

\begin{abstract}
The sintering process is the process of heating a material to increase its strength. The sintering process in ceramic materials can be carried out at a certain temperature. The temperature used depends on the characteristics of the ceramic material itself. In the territory of Indonesia has the potential of ceramic materials so that it is necessary to understand the sintering process sufficient to obtain the expected product characteristics according to the needs of the engineering field. This paper discusses the process of sintering in clay ceramic materials into products and then evaluates changes in dimensions and strength. Clays in the form of large clumps (chunks) are dried in ordinary air by utilizing sunlight for 3 days. Dry lumps of clay are manually crushed into powder. Powder measurement is done by sieving method using mesh 100. The powder is formed in the form of disks and porous cylinders by using compacting method followed by sintering process. Sintering is carried out at $950 \mathrm{C}$ and $1250 \mathrm{C}$. The size of the sintering product is measured using a caliper. Mechanical strength is measured using a three point bending. The sintering process at $1250 \mathrm{C}$ produces the greatest shrinkage and the best bending strength. The size information is needed in the assembly process to become the final product.
\end{abstract}

Keywords: Clay, ceramic, sintering.

\begin{abstract}
Abstrak
Proses sintering adalah proses pemanasan suatu material yang ditujukan untuk meningkatkan kekuatannya. Proses sintering pada material keramik dapat dilakukan pada temperatur tertentu . Temperatur yang dipakai tergantung dari karakteristik material keramik itu sendiri. Di wilayah Indonesia memiliki potensi bahan keramik sehingga diperlukan pemahaman proses sintering yang memadai untuk memperoleh karakteristik produk yang diharapkan sesuai kebutuhan bidang rekayasa. Paper ini membahas tentang proses sintering pada material keramik tanah liat (clay) menjadi produk kemudian dievaluasi perubahan dimensi dan kekuatan. Tanah liat dalam bentuk gumpalan besar (bongkahan) dikeringkan pada udara biasa dengan memanfaatkan panas sinar matahari selama 3 hari. Bongkahan tanah liat yang sudah kering dinacurkan secara manual menjadi bubuk. Pengukuran serbuk dilakukan dengan metode ayakan (sieving) menggunakan mesh 100. Serbuk dibentuk dalam bentuk disk dan silinder berpori dengan metode kompaksi dilanjutkan proses sintering. Sintering dilakukan pada suhu $950 \mathrm{C}$ dan $1250 \mathrm{C}$. Ukuran produk sintering diukur menggunakan caliper. Kekuatan mekanik diukur dengan menggunakan three point bending. Proses sintering pada suhu $1250 \mathrm{C}$ menghasilkan penyusutan yang paling besar dan kekuatan bending yang terbaik. Informasi ukuran sangat diperlukan dalam proses perakitan menjadi produk akhir.
\end{abstract}

Kata kunci: clay/ tanah liat, keramik, sintering

\section{Pendahuluan}

Indonesia memiliki bahan baku tanah liat (clay)yang melimpah. Pada tahun 2015 produk tanah liat di Indonesia berkisar 27 juta $\mathrm{m}^{3}$ [1]. Pemanfaatan tanah liat saat ini sangat bervariasi dari bidang rumah tangga, konstruksi bangunan, komponen kendaraan [2] , komponen pembangkit energi sel bahan bakar [3], industri perminyakan, serta bidang kosmetik [4] [5]. Karakteristik terpenting pada pemakaian tanah liat pada bidang industri adalah ukuran partikel, komposisi kimia, bentuk partikel, sifat fisik dan sifat kimia, porositas serta kekuatan tanah liat setelah mengalami proses sintering [5]. Ukuran partikel dapat diperoleh melalui proses tumbukan dengan peralatan ball mill atau melalui proses tumbukan secara secara manual kemudian dilakukan poroses penyaringan dengan metode sieving (ayakan) [6]. Pada proses pembentukan selanjutnya dilakukan proses kompaksi dalam cetakan (moulding ) untuk memperoleh bentuk tertentu. Ukuran dan bentuk cetakan tergantung dari produk yang diperlukan. Untuk mempermudah pengikatan serbuk tanah liat ditambahkan binder (pengikat) [7] sehingga mudah dibentuk dan serbuk tanah liat mudah merekat. Tahap selanjutnya adalah pengontrolan porositas jika produk tersebut memerlukan porositas sperti produk filter. Pengontrolan porositas biasanya ditambahkan pore former (pembentuk pori). Material pembentuk pori untuk bahan tanah liat dapat dipakai tepung beras atau tepung beras [8]. Pada proses selanjutnya tepung beras terurai dan hilang meninggalkan pori 
(void) terbentuk secara random. Proses penghilangan pore former diproses bersamaan dengan sintering. Proses sintering dikerjakan untuk meningkatkan kekuatan serbuk tanah liat. Konsekuensi dari proses sintering dimensi produk akan mengalami perubahan karena efek pemanasan yang diberikan. Disaat penambahan panas pada saat proses sintering atom atom yang berada pada material tanah liat mudah bergerak mengisi tempat yang kosong akibat proses difusi atom [9] serta bahan yang mudah terbakar seperti binder dan pembentuk pori akan menguap. Efek gerak atom dan menguapnya bahan pengikat dan pembentuk pori mengakibatkan perubahan ukuran produk. Perubahan ukuran produk dari proses sintering akan memberikan informasi yang cukup penting terutama saat mendesain dan merakit semua komponen menjadi produk yang siap dipakai. Paper ini membahas tentang pembuatan produk clay dalam bentuk piringan (disk) dan bentuk silinder berlobang serta kekuatan mekanik terutama kekuatan patah (fracture patah) dimulai dari pembuatan serbuk tanah liat, proses kompaksi dan proses sintering.

\section{Metodologi Penelitian}

Bahan tanah liat diambil dari daerah Plered-Purwakarta, Jawa Barat dalam bentuk bongkahan. Tanah liat ini dikeringkan diudara biasa dibawah terik matahari selama tiga hari. Metodologi penelitian yang dilakukan ditunjukkan dalam diagram alir Gambar 1. Diawali dengan pemilihan material sampai pengeringan bahan baku tanah liat, pembuatan serbuk, proses sintering, pengujian dan pembahasan dan diakhiri dengan kesimpulan.

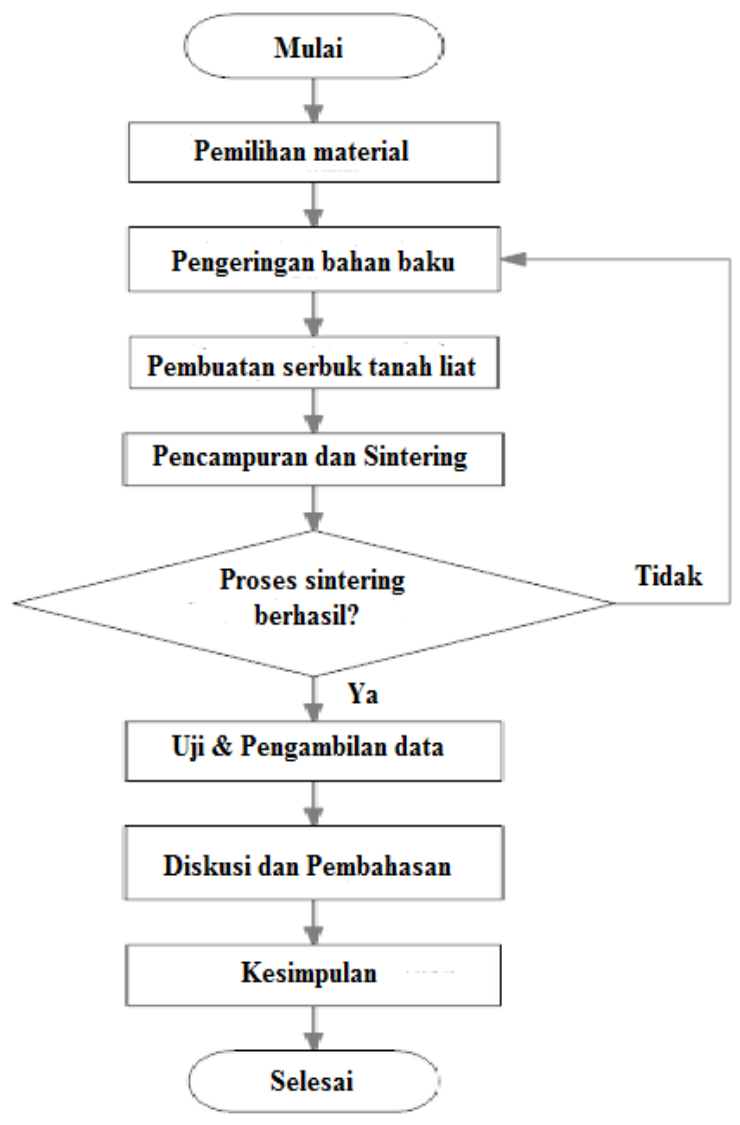

Gambar 1. Metode Penelitian

Pada proses pengeringan bongkahan dijemur selama 3 hari sudah kering. Tanah liat ditumbuk dalam mortar secara manual. Tanah liat dalambentuk serbuk diayak dengan mesh ukuran 100. Dibentuk menjadi piringan dengan tebal 7,4 $\mathrm{mm}$ dan diameter $70 \mathrm{~mm}$. Piringan yang dibuat dikontrol porositasnya dengan menambahkan tepung beras dengan prosentase berat 5\%, $15 \%$ dan $25 \%$. Binder menggunakan PVA cair sebesar $1 \%$ berat. Tekanan kompaksi menggunakan tekanan sebesar 3,5 MPa. Proses mixing dibantu dengan agitator mekanik pada menggunakan motor 220 V, $50 \mathrm{~Hz}$. Agitator mekanik dipakai untuk menghasilkan prose pencampuran yang homogen antara serbuk tanah liat dan tepung beras. Produk yang lain adalah berbentuk silinder berlobang dengan diameter yang besar $107 \mathrm{~mm}$ dan diameter kecil $8 \mathrm{~mm}$ sebanyak 39 lubang, tinggi silinder $70 \mathrm{~mm}$. Pada pembuatan silinder dibentuk semi slurry untuk mudah dibentuk dengan binder air destilasi dan PVA cair. Proses pembuatan silinder tanpa menggunakan tekanan. Produk silinder dikeringkan dikeringkan dalam tungku pada suhu $105 \mathrm{C}$ selama 3 jam. Sedangkan untuk silinder langsung dilakukan proses sintering pada suhu $1250 \mathrm{C}$ dan produk silinder disinter pada suhu 950. Suhu penahanan dilakukan selama 2 jam. Bentuk tanah sebelum dan sesudah proses pembuatan serbuk ditunjukkan dalam Gambar 2. Ukuran serbuk adalah mesh 100 . 


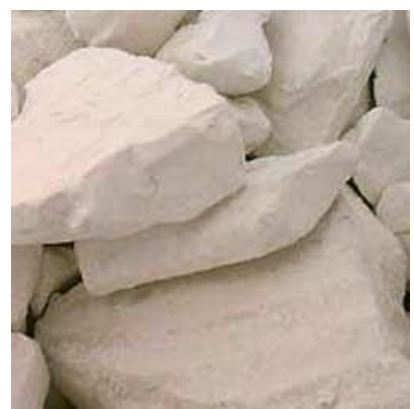

(a)

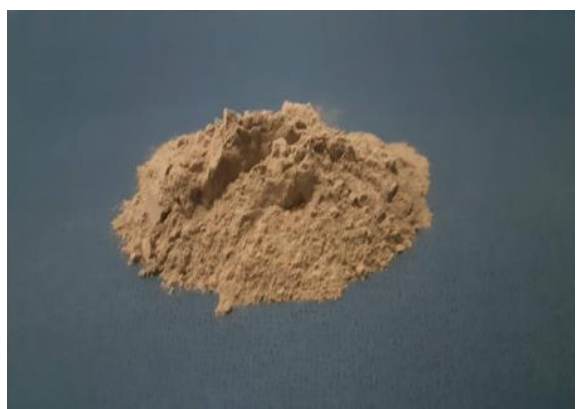

(b)

Gambar 2. Bentuk tanah liat: (a) Bongkahan tanah liat dan (b) Serbuk

Pengukuran dimensi dilakukan dengan caliper digital. Pengukuran diambil saat sebelum pemanasan dan sesudah pemanasan. Pengukuran porositas dilakukan dengan metode archimides. Pengukuran kekuatan patah dilakukan dengan metode three point bending.

\section{Hasil dan Pembahasan}

Hasil pengukuran dimensi dengan menggunakan caliper digital ditunjukan pada Tabel 1 dan Tabel 2. Tabel 1 untuk produk piringan sedang Tabel 2 untuk produk silinder.

Tabel 1. Penyusutan tebal piringan berpori, Tebal awal : 7,4 mm, suhu sintering $1250 \mathrm{C}$

\begin{tabular}{cccc}
\hline No & Clay (gram) & Tepung beras (gram) & Penyusutan $\%$ \\
\hline 1 & 95 & 5 & $18 \%$ \\
2 & 85 & 15 & $26 \%$ \\
3 & 75 & 25 & $27 \%$ \\
\hline
\end{tabular}

Tabel 2. Penyusutan tinggi silinder, Tinggi silinder $70 \mathrm{~mm}$, suhu sintering $950 \mathrm{C}$

\begin{tabular}{lcc}
\hline No & Proses & Penyusutan \% \\
\hline 1 & Dimensi awal & $0 \%$ \\
2 & Pengeringan & $14,3 \%$ \\
3 & Sintering & $6,7 \%$ \\
\hline
\end{tabular}

Tegangan patah pada material berpori ditunjukkan dalam Gambar 3. Grafik hubungan tegangan patah dan jumlah pore former yang ditambahkan dalam tanah liat setelah proses sintering pada suhu $1250 \mathrm{C}$. Semakin banyak pembentuk pori yang ditambahkan, tegangan patah mengalami penurunan. Kondisi ini berkait dengan pembentuk pori meningkat pada produk sinter maka nilai porositas pada tanah liat sinter nilainya meningkat [8].

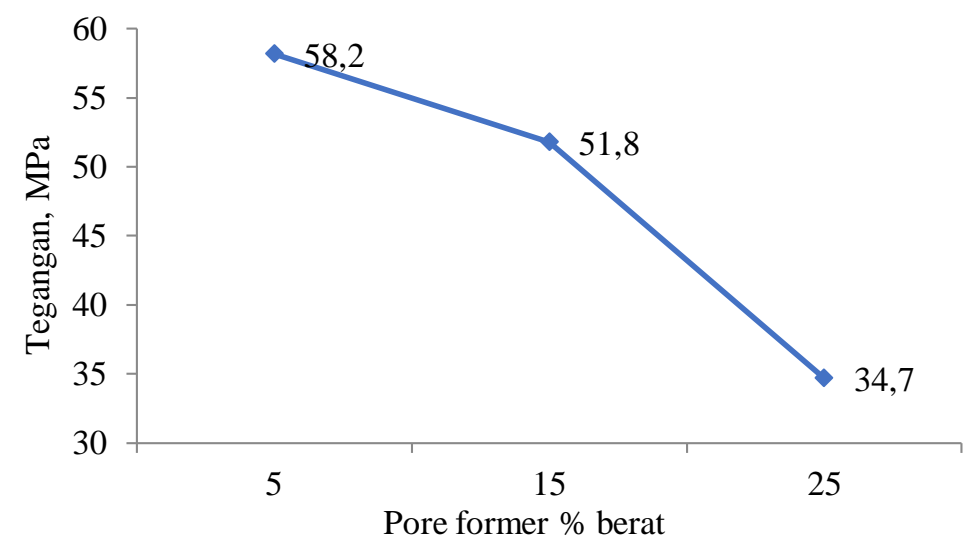

Gambar 3. Hubungan jumlah pore former dan tegangan patah material tanah liat

Proses pemanasan pada proses drying produk silinder seperti pada Tabel 2 menunjukan perubahan dimensi. Kondisi ini terjadi akibat void yang terisi oleh binder air akan hilang. Air menguap meninggalkan void dalam produk dan terisi oleh material tanah liat melalui proses difusi atom [10] yang ada pada tanah liat tersebut sehingga ukuran produk. 
Proses difusi suatu atom pada produk dapat terjadi karena ada energi yang dimiliki oleh atom sehingga mampu bergerak dan mampu menempati pada energi yang lebih rendah yaitu pada sisi void didalam material [11]. Fenomena sintering secara detail diilustrasikan pada Gambar 4. Serbuk yang menempel diilustrasikan seperti 2 bola yang berimpit, kemungkinan difusi atom dapat terjadi karena atom memiliki energi yang diakibatkan panas yang diberikan dari panas tungku.

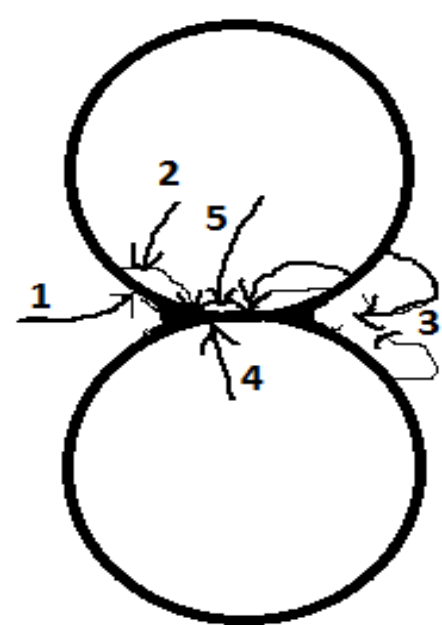

Gambar 4. Ilustrasi fenomena difusi selama proses sintering [12] [12]

Beberapa fenomena difusi yang terjadi selama proses sintering seperti yang diilustrasikan pada Gambar 4 adalah

1. Difusi permukaan

3. Difusi kisi

4. Difusi evaporasi

5. Difusi batas butir

6. Difusi kisi

Pada proses sintering yang mengakibatkan terjadinya densifikasi pada serbuk yang dominan adalah difusi batas butir dan difusi kisi pada no 4 dan no5 [10]. Proses difusi atom ini akan mengisi void yang ada dan membentuk neck atau leher pada serbuk satu dengan serbuk saling berkait membentuk ikatan yang sangat kuat [13]. Kondisi ini ditunjukan pada grafik gambar 2 hubungan antara jumlah pembentuk pori dengan tegangan patah. Semakin banyak jumlah pembentuk pori yang ditambahkan akan meningkatkan nilai porositas dan akan mengurangi kekuatan patah. Pada jumlah pembentuk pori semakin sedikit maka void yang terbentuk semakin sedikit maka void yang terisi oleh atom semakin banyak. Dengan demikian produk semakin rapat (dense). Produk semakin rapat makan kekuatan patah semakin tinggi. Pada gambar 2 ditunjukkan bahwa pada jumlah penambah pori $5 \%$ maka kekuatan patahnya sebesar 58,2 MPa, sedang pada penambah pori sebanyak $25 \%$, kekuatan patah sebesar 34,7 Mpa [14].

Disamping efek kekuatan, efek dimensi juga sangat dipengaruhi oleh jumlah pembentuk pori. Semakin banyak pembentuk pori maka perubahan dimensi semakin besar. Pada Tabel 1untuk penambahan pembentuk pori tepung beras sebesar $5 \%, 15 \%$ dan $25 \%$ berat maka penyusutannya pada bentuk piringan adalah sebesar $18 \%, 25 \%$ dan $27 \%$, sedangkan untuk bentuk silinder yang dibentuk dengan semi slurry maka pada proses pengeringan (drying) pada suhu sebesar $105 \mathrm{C}$, penyusutan ukuran tinggi silinder sebesar 14,3\%, kemudian dilanjutkan pada proses sintering mengalami penyusutan sebesar 6,7 \%. Pada proses pengeringan bentuk silinder pada suhu $105 \mathrm{C}$ sudah mampu menguapkan air sehingga rongga yang terisi air kosong membentuk pori dan ada atom atom yang berdifusi sehingga ukurannya menyusut $[8,10]$. Pada proses sintering selanjutnya binder yang masih ada di dalam produk silinder belum dapat menguap pada suhu 105 C. Binder PVA (polyvinil alcohol) mendidih pada suhu $228 \mathrm{C}$ [15] sehingga pada suhu sintering $950 \mathrm{C}$ mampu menghilangkan PVA. PVA yang menguap akan meninggalkan void dan terjadi difusi dan meningkatkan densitas. Proses ini akan menyebabkan perubahan dimensi yaitu produk mengalami penyusutan dan dapat meningkatkan kekuatannya[14].

\section{Kesimpulan}

Pada proses pembuatan produk dengan material serbuk dari tanah liat yang melalui proses kompaksi, pengeringan dan proses sintering maka produk tersebut akan mengalami perubahan ukuran. Informasi perubahan ukuran sangat penting pada produk akhir sehingga memudahkan proses perakitan. Disamping mengalami penyusutan akibat proses sintering dapat meningkatkan kekuatannya. Pada proses sintering dengan memanfaatkan pembentuk pori tepung beras, penyusutan terbesar pada pembentuk pori $25 \%$ dengan nilai penyusutan sebesar $27 \%$. Kekuatan patah (fracture strength) tertinggi diperoleh pada penambahan tepung beras sebesar $5 \%$ berat dengan kekuatan patah sebesar 58,2 MPa 
pada suhu sintering $1250 \mathrm{C}$. Proses peningkatan kekuatan patah dan penyusutan produk tanah diakibatkan oleh proses difusi.

\section{Ucapan Terima Kasih}

Kami mengucapakn terima kasih kepada beberapa pihak yang telah membantu lancarnya penelitian ini, terutama pada saat pemakaian peralatan yang ada di Departemen Teknik Mesin Fakultas Teknik Undip yang berupa peralatan tungku pemanas, peralatan uji bending untuk mengetahui kekuatan patah dan semua pihak yang telah membantu suksesnya penelitian ini.

\section{Referensi}

[1] B. S. Sodikin, M.Sat, R. Gumelar, Statistik Pertambangan Bahan Galian Indonesia. Badan Pusat Statistik Indonesia, 2016.

[2] A. Ghofur, A. Hadi, and M. D. Putra, "Potential fly ash waste as catalytic converter for reduction of $\mathrm{HC}$ and $\mathrm{CO}$ emissions," Sustain. Environ. Res., pp. 1-6, 2018.

[3] J. A. Cebollero, R. Lahoz, and A. Larrea, "Tailoring the electrode-electrolyte interface of Solid Oxide Fuel Cells ( SOFC ) by laser micro-patterning to improve their electrochemical performance," J. Power Sources, vol. 360, pp. 336-344, 2017.

[4] H. H.Murray, "Overview- clay mineral applications," Appl. Clay Sci., vol. 5, no. 5-6, pp. 379-395, 1991.

[5] M. I. Carretero, "Clay minerals and their beneficial effects upon human health . A review," vol. 21, pp. 155-163, 2002.

[6] T. Hanke and R. Gmbh, "Sieve Analysis Different sieving methods for a variety of applications," no. August, 2016.

[7] Y. B. Khosrowshahi and A. Salem, "Cerámica y Vidrio A view on organic binder effects on technical properties of ceramic Raschig rings," pp. 335-342.

[8] S. Sulistyo, "Porosity Control and Mechanical Properties of Porous Ceramic Material from Plered Region," in MATEC Web of Conferences 159, 02004 (2018) IJCAET \& ISAMPE 2017, 2018, vol. 02004, pp. 1-5.

[9] M. Rundans and I. Sperberga, "Effect of sintering process and additives on the properties of cordierite based ceramics," no. April, 2015.

[10] R. M. German, "Sintering Trajectories : Description on How Density , Surface Area , and Grain Size Change," vol. 68 , no. 3, pp. 878-884, 2016.

[11] R. Grupp, M. Nöthe, B. Kieback, and J. Banhart, "Cooperative material transport during the early," Nat. Commun., vol. 2, no. May, pp. 296-298, 2011.

[12] Xiaolin Chen, "Particle Packing, Compaction and Sintering in Powder Metallurgy," 1998.

[13] H. Mehrer, Diffusion in Solids Fundamentals, Methods, Materials, Diffusion-Controlled Processes. 2007.

[14] J. W. Fergus, Solid Oxide Fuel Cell Materials Properties and Performance. Nort West, Boca Raton USA: CRC Press, 2009.

[15] M. Aslam, M. A. Kalyar, and Z. A. Raza, "Polyvinyl alcohol: A review of research status and use of polyvinyl alcohol based nanocomposites Polyvinyl Alcohol: A Review of Research Status and Use of Polyvinyl Alcohol Based Nanocomposites," no. April, 2018. 